\title{
Characterization of Polyurethan Skin Agglomerates for Acoustic Insulation from Impact Noise
}

\author{
W. B. Ribeiro, M. V. Rizzo, N. Bortoluz, M. Zeni, M. F. O. Nunes*, A. M. C. Grisa \\ University of Caxias do Sul - UCS, Francisco Vargas Street, 1130. Caxias do Sul, RS, Brazil
}

Received: June 27, 2013; Revised: July 15, 2014

\begin{abstract}
Polymeric materials are greatly used in industry due to their versatility in application generating therefore, large quantities of solid waste. Population growth in urban areas, with living quarters mainly in residential buildings, face discomfort caused by noise, particularly by impact noise. Aiming at reducing the amount of polymeric material disposed of in the environment and at providing alternatives of reuse, together with the possibility of reducing noise impact from construction works, agglomerates of polyurethane skin (PUs) have been developed. The recycling process of PUs was developed through variations in particle size and pressing temperature of agglomerates. PU agglomerates of coarse particle size, hot pressing process and close cell structure presented reductions in noise level up to $20 \mathrm{~dB}$, showing that it is suitable for acoustic insulation.
\end{abstract}

Keywords: acoustic insulation, polyurethane skin, recycling

\section{Introduction}

Population growth in urban areas with the resultant proximity of people's homes has developed the need for greater privacy. Soundproofing became an essential feature for good neighboring; especially sound insulation of impact noise, given that many buildings are multi-storey. In Brazil, as opposed to countries such as France, Germany, England, and the $\mathrm{USA}^{1}$, the requirement for sound insulation in residential buildings is very recent, with the adoption of the standard building performance NBR 15575.

Civil construction is a significant consumer of products whose environmental impact can be minimized by recycling, particularly the recycling of polymeric materials ${ }^{2}$. Polyurethane (PU) is a polymer that has drawn increasing attention in recycling because there are many different PU types, systems or families, and such material can be rigid or flexible ${ }^{3}$. Because of its chemical structure, PU degrades slowly, which damages the environment ${ }^{4}$.

The construction and renovation of buildings demands a large variety of materials. In the selection of such materials, an increasing concern is the improvement of acoustic comfort. Ambient comfort is determined by the acoustic insulation of the construction and can be classified in different ways depending on how well a given material can insulate the noise. The noises that cause most discomfort inside buildings are the noises produced, for example, by individuals walking and shifting furniture. Furthermore, poor sound insulation of a building can also generate costs related to depreciation of properties in noisy areas ${ }^{5}$.

Acoustic design involves elastic waves propagation in materials and interaction of sound waves with the structures ${ }^{6}$. The first attempts at sound insulation adopted the same methods and materials used for thermal insulation and these efforts were largely unsuccessful because heat and sound do

*e-mail: mfonunes@ucs.br not travel by the same process. Consequently, materials that are used as efficient thermal insulators do not necessarily possess the properties needed to be good sound insulators? This issue is particularly important when it comes to the two different means of sound transmissions in buildings: by air - airborne noise, and the rigid structure - impact noise. As to airborne noise, some fibrous materials used for thermal insulation can provide good sound insulation. However, for impact noise insulation the material must have damping and absorption of the vibration caused by a mechanical impact ${ }^{8}$.

Impact noise transmission can be minimized by using vibration isolation systems, and floating floors are one of the most effective means to decrease impact sound ${ }^{9}$. In such floors, a layer of a resilient material, or elastic base is placed between the concrete slab and the load plate. Currently, the most commonly used materials are made of polymer, which offers a wide range of recycling possibilities ${ }^{10}$.

The material used as an elastic base for floating floors must be compression resistant and possess an anisotropic pore structure. They are usually fibrous materials such as stone or glass wool and polymeric foams and elastomers. The principle for cushioning the impact on these materials is associated with the type of cell: open for fibrous materials and closed or partially closed for the others.

These materials are given the weight of the subfloor and the floor covering and they are susceptible to deformations that can change their damping capacity throughout time. This subject was investigated by Dikavičius and Miškinis ${ }^{11}$ and they found different alterations in damping capacity for mechanical impact in floating flooring materials with higher losses in the damping fibrous material with open cells, comparing with close cells materials. Furthermore, Peters ${ }^{9}$ analyzed that the different types of resilient materials used as isolators of vibration show different behaviors at different frequencies. Also, at the high frequency end of the range, 
where static deflections are small, cork, cork composites, felt, foamed plastic and foamed rubber may be used in the form of pads or mats. All these materials have part of their springiness given by the way the air is hold and thus used in compression.

Several studies compare the use of recycled polymer materials to decrease impact noise to the use of conventional products. Some of these materials use various residues, such as carpet fibres ${ }^{12}$, elastomers ${ }^{10,13}$ and polymers discarded by the footwear industry ${ }^{14,15}$.

PU skin is a material that possesses a flexible cellular nucleus (foam) coated with a smooth superficial non-porous skin $1 \mathrm{~mm}$ to $5 \mathrm{~mm}$ thick which protects the interior of the material against mechanical loads ${ }^{3}$. These characteristics indicate a strong potential for the use as an elastic base for floating floors.

This paper proposes the manufacturing and characterization of PUs agglomerates through physical, mechanical and morphological properties for the purpose of acoustic insulation in floors of buildings.

\section{Material and Methods}

\subsection{Material}

The material used was PUs waste donated by Multispuma Industria e Comercio Ltda, a company in Caxias do Sul. Pre-polymers based on saturated polyester resin and diphenylmethane diisocyanate (MDI) from BASF Polyurethane Ltda and Jimo® silicone spray release agent.

\subsection{Milling of PU skin residues}

The PUs residues were milled in a knife mill and a granulometric test was then performed using a vibratory strainer. The granular solid retained in the strainers of 0.84 to $2.00 \mathrm{~mm}$ was denominated coarse particle size $(\mathrm{G})$, and the solids retained in the strainer of $0.84 \mathrm{~mm}, 0.54 \mathrm{~mm}$ and at the bottom were called fine particle size $(\mathrm{F})$.

\subsection{Preparation of $P U$ skin agglomerates}

PUs agglomerates were obtained mixing 80 to 120 parts of solid granular PUs, 20 to 40 parts of pre-polymer and 3 parts of water. After homogenization, the mixture was poured into an $89 \times 59 \mathrm{~cm}$ hydraulic press, with molding compression at a pressure of $2066 \mathrm{~N} \mathrm{~m}^{-2}$, at the constant temperature of $40{ }^{\circ} \mathrm{C}$ and demolding time of 45 minutes. Demolding time for cold pressed PUs agglomerates was 24 hours.

The acronyms used for PUs agglomerates were as follows: PUGQ standing for PU granular solids of coarse particle size and pressed hot; PUGF coarse particle size and pressed cold, PUFQ fine particle size and hot pressing and PUFF fine particle size and cold pressing.

\subsection{Characterization of PUs agglomerates}

\subsubsection{Bulk density}

Tests of bulk density of PUs agglomerates were performed according to NBR $14810-3^{16}$, in three replications. Bulk density was determined using Equation 1:
$D=\frac{m}{V}$

Where: $\mathrm{D}$ is the density $\left(\mathrm{kg} / \mathrm{m}^{3}\right), \mathrm{m}$ is the mass of the sample $(\mathrm{kg})$, and $\mathrm{V}$ is the sample volume $\left(\mathrm{m}^{3}\right)$.

\subsubsection{Acoustic isolation from impact noise}

The insulation test for impact noise was performed in two superimposed rooms separated by a concrete slab where the upper room was the emission and the bottom room the reception. $1 \mathrm{~m}^{2} \mathrm{PU}$ skin plates were assessed, positioned at the center of the room and a $1000 \times 1000 \times 50 \mathrm{~mm}$ concrete load plate was placed over them, similarly to floating floors compositions with a resilient layer. For comparative purposes, the plate above the concrete layer was also tested without the resilient material. On it, a standard impact sound source Brüel \& Kjaer tapping machine was positioned. This test is designed to simulate the effects of impact noise such as footsteps or the dragging of furniture coming from upstairs ${ }^{9}$. In the reception room four points were set for the sound analyzer, according to ISO $140-7^{17}$ procedures. The noise measurements were performed with a Quest Technologies, Class 1, acoustic analyzer positioned on a tripod.

\subsection{Mechanical characterization of PUs agglomerates}

\subsubsection{The compressive strength test}

The compressive strength test was performed according to NBR $8797^{18}$ using the universal testing machine EMIC, DL model. The applied load was distributed evenly over the specimen, compressing from 50 to $90 \%$ of its thickness.

\subsubsection{Resilience}

The resiliency test was performed according to NBR $8619^{19}$ and it was run before and after the compressive strength test. The test consisted in dropping a $16 \mathrm{~mm}, 16.7 \mathrm{~g}$ steel ball over the samples. The resilience was recorded at the maximum rebound height of this ball. To determine the rebound rate of the material, the test results were expressed in percentages.

\subsubsection{Test of loss through abrasion}

The abrasion test was conducted according to ASTM D5963-04 ${ }^{20}$ using the Martec-Maqtest device over two cylindrical specimens of $16 \mathrm{~mm}$ of diameter and $3 \mathrm{~mm}$ of length. The specimens were weighed and then subjected to abrasive sandpapering action. They were fixed on the rotary cylinder, with the total test length equivalent to 40 meters. At the beginning and at the end of each test, the sample was weighed on an analytical scale allowing for the calculation of weight loss of the material.

\subsection{Morphological characterization}

\subsubsection{Scanning electron microscopy}

The morphology of PUs agglomerates was analyzed by Scanning Electron Microscope (SEM). The samples were fractured in $\mathrm{N}_{2}$ at $-140{ }^{\circ} \mathrm{C}$ and metalized through a sputtering with a thin gold layer on the surface. Images were obtained via electron accelerating voltage of $1 \mathrm{kV}$ and increases of 100,300 and 500 times.. 


\section{Results and Discussion}

\subsection{Density}

The average density values of the agglomerates were conducted in three replications and are showed in Table 1.

The PUFF agglomerate showed the highest density comparing with PUGQ, PUGF and PUFQ. Possibly due to the pre-polymer added being denser than the granular solids of PUs insofar as it affects the compaction and adherence of granular solids. Low-density materials are usually better for sound attenuation, due to the increase in air content ${ }^{21}$. Furthermore, the speed of sound goes down as the density of a material goes up because the energy used to generate sound is converted into momentum of the molecules ${ }^{7}$.

Smaller densities were observed in materials with coarse grain size because the voids between the grains of PU allow greater air trapping and consequent reduction in its mass.

\subsection{Acoustic insulation from noise impact}

The analysis of sound insulation is based on procedures of three different standards. The test method is given by ISO140-7 ${ }^{17}$, achieving values of sound levels for different frequencies analyzed. The ISO $717-2^{22}$ shows the procedure for processing these partial results by frequency into a single number that translates the performance of the flooring system. From that number is done the performance rating, which has different limits in different countries. In Brazil, the standard for performance rating is the NBR $15575^{23}$.

Analysis of the acoustic test results were performed by comparing the noise level curve $\left(\mathrm{L}_{\mathrm{n}}\right)$ of the concrete load plate as well as of each PUs slab tested. The performance rating was obtained in $\mathrm{L}$ " ${ }_{n T, W}$.

Comparing the noise levels of the agglomerates and the concrete slab (Figure 1), it was possible to observe a reduction at all frequencies except the frequency of $200 \mathrm{~Hz}$, which is characterized as the system resonant frequency.

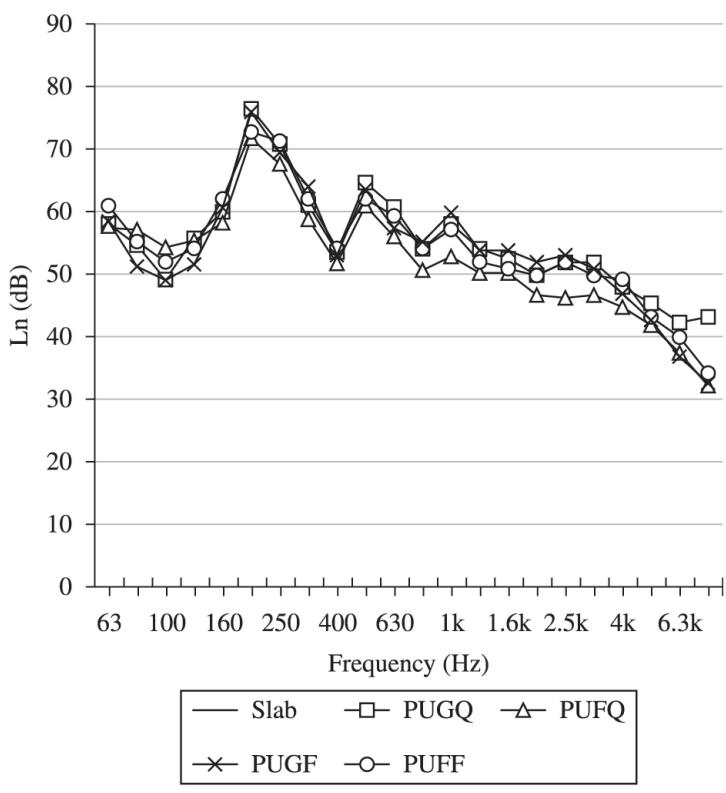

Figure 1. Sound pressure levels of standardized impact $\mathrm{L}_{\mathrm{n}}$.
The behavior of the sound spectrum for the four samples is similar, but it is worth to mention that the agglomerate PUGF emitted lower noise levels at frequencies below $160 \mathrm{~Hz}$, and the agglomerate PUFQ at frequencies above $1000 \mathrm{~Hz}$. The most significant reduction was in the high frequencies above $1000 \mathrm{~Hz}$ due to the higher sensitivity of the human ear to this sound pitch ${ }^{9}$. Thus, when a material provides greater isolation at high frequencies, people have a more comfortable environment.

The concrete slab without treatment for impact noise mitigation in relation to the underlayment showed minimal performance according to NBR $15575^{23}$, lower than $80 \mathrm{~dB}$. The agglomerates yielded results that allowed for differentiation of the plates according to the type of PU skin particle size and the type of pressing. Agglomerates of coarse particle size had an intermediate performance of $59 \mathrm{~dB}$ for both types of pressing. Agglomerates of fine particle size and hot pressing displayed a significant higher performance of the material of $\mathrm{L}_{\mathrm{nT}, \mathrm{w}} 55 \mathrm{~dB}$ (Table 2).

\subsection{Compressive strength}

Table 3 presents the results of the compressive strength of the PU skin agglomerates after $50 \%$ of their thickness was compressed.

The PUGF agglomerate of lower density value had the lowest deflection and lower compressive strength, demonstrating that density somehow plays a role in determining the compressive strength, whereas a decrease in the values of compressive strength highlights property loss ${ }^{21}$.

The compressive strength deformation is particularly important for the intended use of the agglomerates because of the permanent weight on top of these resilient bases in

Table 1. Bulk density of the PUs agglomerates.

\begin{tabular}{cc}
\hline Agglomerates & Density $\left(\mathbf{k g} / \mathbf{m}^{3}\right)$ \\
\hline PUGQ & $324.40 \pm 0.52$ \\
PUGF & $313.16 \pm 0.55$ \\
PUFF & $366.33 \pm 0.49$ \\
PUFQ & $342.32 \pm 0.49$ \\
\hline
\end{tabular}

Table 2. Classification of acoustic performance.

\begin{tabular}{ccc}
\hline Material & $\mathbf{L}_{\mathbf{n T , W}}(\mathbf{d B})$ & $\begin{array}{c}\text { Performance Rating } \\
\text { NBR 15.575 }\end{array}$ \\
\hline Concrete Layer & 75 & Minimal \\
PUGQ & 55 & Superior \\
PUGF & 58 & Intermediate \\
PUFF & 59 & Intermediate \\
PUFQ & 59 & Intermediate \\
\hline
\end{tabular}

Table 3. Compressive strength of the PUs agglomerates.

\begin{tabular}{cc}
\hline Agglomerates & $\begin{array}{c}\text { Compressive strength at } \\
\mathbf{5 0 \%} \text { deformation (MPa) }\end{array}$ \\
\hline PUGQ & $0.33 \pm 0.049$ \\
PUGF & $0.16 \pm 0.013$ \\
PUFF & $0.24 \pm 0.027$ \\
PUFQ & $0.44 \pm 0.123$ \\
\hline
\end{tabular}


floating floors that receive the load of the subfloor, floorings and furniture.

\subsection{Resilience}

Table 4 shows the results of compression resilience of PUs agglomerates.

PUs agglomerates are considered highly resilient. Thereby, they recover fast and resist compression without loss in attenuation of mechanical impact ${ }^{9}$. This resilient material is are like a spring that is not rigidly attached to the structure. Therefore, vibration and noise are not easily transferred to the building ${ }^{7}$.

On the other hand, the biggest problem of the resilient layer is that it is sufficiently rigid to ensure good stability, but it is less efficient in providing high degrees of isolation. So, it is necessary to have a balance between the mechanical and acoustic properties. Eaves $^{3}$ explains the relation between density and elasticity of PU materials used as the basis of resilient floating floors and considering the suitable use for impact noise insulation. He says that the higher the density, the higher will the dynamic modulus of elasticity be.

This relation is observed in the studied agglomerates because the greater resilience also corresponds to higher density.

\subsection{Testing of losses due to abrasion}

Table 5 presents values of mass loss of PUGQ agglomerate.

A material mass loss of about $30 \%$ occurred because the agglomerate was porous and brittle, probably due to its agglomeration process.

The test of loss due to abrasion of PUGF, PUFF and PUFQ agglomerates were not performed because they could not be fixed onto the equipment or because they broke as soon as they touched the surface of the cylinder. The curing time of the granular solid and the pre-polymer was possibly effective, but the amount of pre-polymer used may have caused agglomeration, making them brittle.

\subsection{Scanning electron microscopy}

The PUGQ sample (Figure 2) did not present a uniform structure. It was composed mostly by open-cells and some closed cells segments, which explains the results obtained in terms of the sound insulation testing.

The PUGF sample micrograph (Figure 3) shows a more uniform structure with homogeneous distribution of open cells.

The cells size average distribution in the PUGQ agglomerate rated at $126.37 \mu \mathrm{m}$ and the PUGF agglomerate

Table 4. Resilience test of PUs agglomerates.

\begin{tabular}{ccc}
\hline Agglomerates & $\begin{array}{c}\text { Resilience before compression } \\
(\boldsymbol{\%})\end{array}$ & $\begin{array}{c}\text { Resilience after compression } \\
(\boldsymbol{\%})\end{array}$ \\
\hline PUGQ & $41.1 \pm 0.69$ & $40.4 \pm 1.34$ \\
PUGF & $39.8 \pm 0.38$ & $40.1 \pm 0.50$ \\
PUFF & $44.1 \pm 1.17$ & $43 \pm 1.20$ \\
PUFQ & $40 \pm 0.20$ & $42 \pm 0.81$ \\
\hline
\end{tabular}

Table 5. Loss due to abrasion of the PUGQ agglomerate.

\begin{tabular}{cccccc}
\hline Agglomerate & Diameter $(\mathbf{m m})$ & Thickness $(\mathbf{m m})$ & Weight before $(\mathrm{g})$ & Weight afterwards $(\mathrm{g})$ & Weight loss $(\mathrm{g})$ \\
\hline PUGQ & 15.13 & 12.71 & 0.95 & 0.67 & 0.288 \\
\hline
\end{tabular}

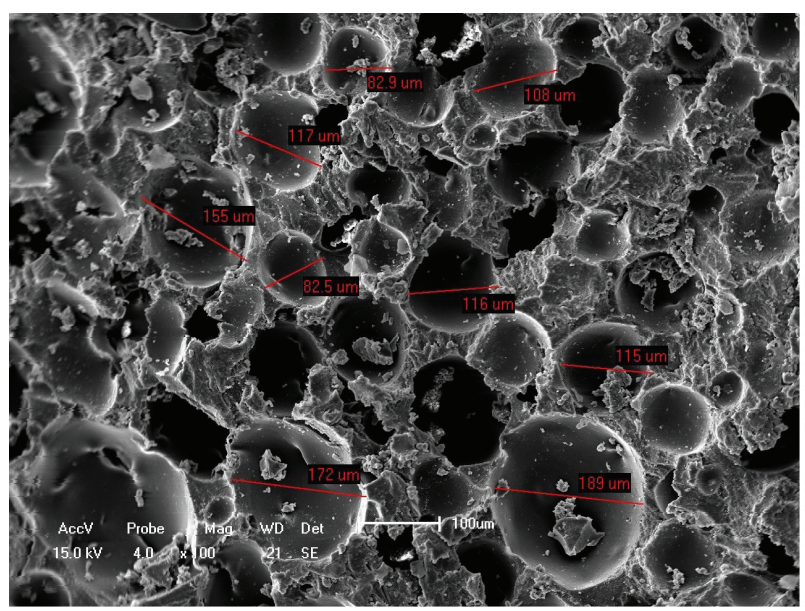

(a)

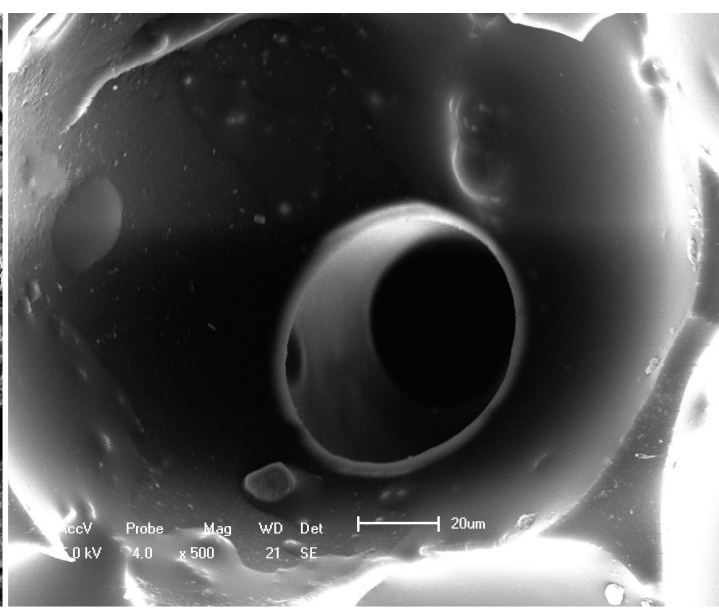

(b)

Figure 2. PUGQ agglomerate micrograph (a) 100X and (b) 500X. 


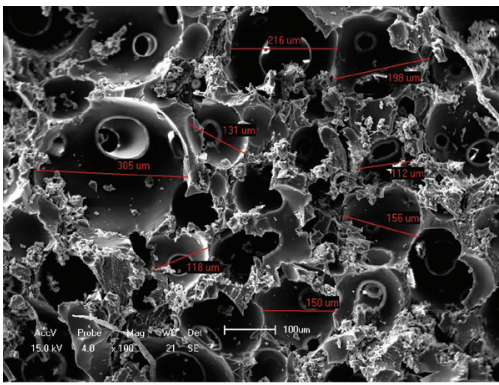

(a)

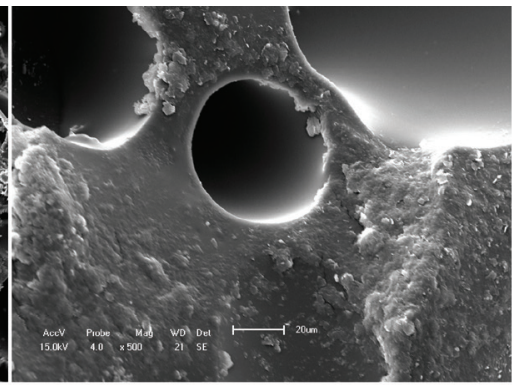

(b)

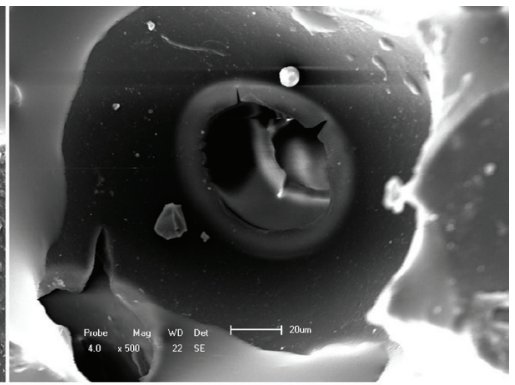

(c)

Figure 3. PUGF agglomerate micrograph (a) 100X and (b, c) 500X.

at $173.25 \mu \mathrm{m}$, both displaying small cells, which offer a higher acoustic performance ${ }^{11}$. However, in floating floors using foams of low density open cell resilient layers, deformations can be observed when walking on, thus requiring a more rigid material to avoid problems due to fatigue in the joints of the coating. Closed cell foams are more rigid than the open cell ones due to the effect of the air inside the cell and they must be used in strips alternating with open cell foams ${ }^{24}$.

\section{Conclusions}

The material proposed in this paper aims to meet a specific use in case of resilient bases for floating floors with PU skin waste. For this purpose, tests with different pressing temperatures and particle sizes indicating the most suitable way for the fabrication of this material were performed.

Coarse particle size of the solids of PU skin, hot pressing and close cells in agglomerates, showed a difference in

\section{References}

1. Zannin PHT and Ferreira JAC. In situ acoustic performance of materials used in Brazilian building construction. Construction and Building Materials. 2007; 21(8):1820-1824. http://dx.doi.org/10.1016/j.conbuildmat.2006.05.015

2. Pendhari SS, Kant T and Desai YM. Application of polymer composites in civil construction: A general review. Composite Structures. 2008; 84(2):114-124. http://dx.doi.org/10.1016/j. compstruct.2007.06.007

3. Eaves D. Handbook of polymer foams. Shawbury: Smithers Rapra Publishing; 2004.

4. Zia KM, Bhatti HN and Bhatti IA. Methods for polyurethane and polyurethane composites, recycling and recovery? A review. Reactive and Functional Polymers. 2007; 67(8):675692. http://dx.doi.org/10.1016/j.reactfunctpolym.2007.05.004

5. Romo Orozco JM, Marmolejo Duarte $\mathrm{C}$ and Daumal Domènech F. ¿ Cuánto estamos dispuestos a pagar por vivir mejor insonorizados?? Un análisis para el mercado residencial de Barcelona. Revista De La Construcción. 2013; 12(2):88-101. http://dx.doi.org/10.4067/S0718-915X2013000200007

6. Ramezani H, Shahdab S and Nouri A. Study on effects of wood fiber content on physical, mechanical, and acoustical properties of wood-fiber-filled gypsum composites. Materials acoustic noise level of up to $20 \mathrm{~dB}$, indicating that the PU skin is a good acoustic insulator.

The test values for the resilience indicated that these agglomerates are highly resilient, recovering faster from deformation and absorbing more energy, which makes them suitable noise insulators for floors.

PUs agglomerates cells are tiny and have an elliptical shape, influencing the decrease of compression strength of the plates.

The use of PUs to make agglomerates in soundproofing from impact noise is viable and can be used in buildings generating savings in production costs and adding to sustainability.

\section{Acknowledgements}

The authors thank FAPERGS, the BASF Company, Multispuma Industry and Trade Ltd. and the University of Caxias do Sul (UCS).

Research. 2012; 15(2):236-241. http://dx.doi.org/10.1590/ S1516-14392012005000018

7. Mooney JW. Practical architectural acoustics notebook. New York: KJWW; 2012.

8. Hassan OAB. Building acoustics and vibration: theory and practice. London: World Scientific Publishing Company, Incorporated; 2009. 947 p. http://dx.doi.org/10.1142/7165

9. Peters RJ. Acoustics and noise control. New Jersey: Taylor \& Francis; 2013.

10. Maderuelo-Sanz R, Martín-Castizo M and VílchezGómez R. The performance of resilient layers made from recycled rubber fluff for impact noise reduction. Applied Acoustics. 2011; 72(11):823-828. http://dx.doi.org/10.1016/j. apacoust.2011.05.004

11. Dikavi ius V and Miškinis K. Change of dynamic stiffness of open and closed cell resilient materials after compressibility test. Materials Science. 2009; 15(4):1-4.

12. Rushforth IM, Horoshenkov KV, Miraftab M and Swift MJ. Impact sound insulation and viscoelastic properties of underlay manufactured from recycled carpet waste. Applied Acoustics. 2005; 66(6):731-749. http://dx.doi.org/10.1016/j. apacoust.2004.10.005

13. Benkreira H, Khan A and Horoshenkov KV. Sustainable acoustic and thermal insulation materials from elastomeric 
waste residues. Chemical Engineering Science. 2011; 66(18):4157-4171. http://dx.doi.org/10.1016/j.ces.2011.05.047

14. Branco FG and Godinho L. On the use of lightweight mortars for the minimization of impact sound transmission. Construction and Building Materials. 2013; 45:184-191. http:// dx.doi.org/10.1016/j.conbuildmat.2013.04.001

15. Tutikian BF, Nunes MFO, Leal LC and Marquetto L. Impact sound insulation of lightweight concrete floor with EVA Waste. Building Acoustics. 2012; 19(2):75-88. http://dx.doi. org/10.1260/1351-010X.19.2.75

16. Associação Brasileira de Normas Técnica - ABNT. NBR 148103: chapas de madeira aglomerada. Parte 3: métodos de ensaio. Rio de Janeiro: ABNT; 2006.

17. International Organization for Standardization - ISO. ISO 140-7. Acoustics: measurement of sound insulation inbuilding elements. Part 7 Field measurements of impact sound insulation of floors. Geneva; 1998.

18. Associação Brasileira de Normas Técnicas - ABNT. NBR 8797: espuma flexível de poliuretano: determinação da deformação permanente à compressão. Rio de Janeiro; 2003.
19. Associação Brasileira de Normas Técnicas - ABNT. NBR 8619: espuma flexível de poliuretano: determinação da resiliência. Rio de Janeiro; 2003.

20. American Society for Testing and Materials - ASTM. ASTM D 5963-04: Standard test method for rubber property: abrasion resistence (Rotary drum abrader). West Conshohocken; 2010.

21. Klempner D, Sendijarevic V and Aseeva RM. Polymeric foams and foam technology. Munich: Hanser Publishers; 2004. 584 p.

22. International Organization for Standardization - ISO. ISO 717-2: acoustics: rating of sound insulation in buildings and of building elements. Part 2: impact sound insulation. Geneva; 2013.

23. Associação Brasileira de Normas Técnicas - ABNT. NBR 15575-3. Edifícios habitacionais: desempenho. Parte 3: requisitos para os sistemas de pisos. Rio de Janeiro; 2013.

24. Stewart MA, Crak RJM. Impact sound transmission through a floating floor on a concrete slab. Applied Acoustics. 2000; 59(4):353-372. http://dx.doi.org/10.1016/S0003$682 \mathrm{X}(99) 00030-4$ 